\title{
Karen's Story
}

\section{Heather Thompson \\ Class of 2011, Faculty of Medicine, Dalhousie University}

S oaring. As she felt the music swell, her legs moved effortlessly under her, gathering strength and speed, her whole body aching with the tension of the music and the burning of her exhausted muscles. As the song finally climaxed, she exploded into the air in a grand jeté, her back arching in perfect harmony with the music, arms and legs extended outwards, as if to capture something just beyond her reach, as if by straining that little bit harder, she could stay suspended in the air, free, weightless, for just a moment longer.

As she landed, hearing the satisfying thump of her woodentoed pointe shoes on the stage, she could hear the audience burst into applause. Exhausted, chest heaving, muscles quivering, she managed a smile. She looked up into the bright, hot lights, still savouring the feeling of glorious harmony when body, music, and spirit melded in perfect synchrony.

But as her heart slowed, and her eyes stopped tearing from the blinding stage lights, she realized that it was not applause she was hearing, nor was it an audience she was looking out upon. The warm caress of the yellow stage lights had withdrawn, replaced instead by intrusive, cold, white beams. The whistles of admiration morphed instead into the mechanical, calculating beeps of a heart monitor and terse voices shouting words she didn't understand. Her chest was bare, breasts exposed. She knew she should be afraid; after all, she didn't know exactly where she was or why, but instead all she could think of was how her bare chest exposed her tiny breasts and how the cute doctor, or paramedic, or whoever he was, must think she was only 12 or something. She wanted to ask someone where she was and what had happened to the concert hall, but she was tired, so tired...Her eyes fluttered. Through the mêlée, she could hear a voice calling her, "Karen! Karen!"

\section{"Karen!"}

Karen's eyes flew open in a panic at the sound of her mother's voice as she tried to orient herself. She let out a sigh of relief as she realized she was no longer in a hospital, but safe in her bed. Only a nightmare, thank goodness. Then she remembered.

Karen froze and tensed again, fists clenched, permitting only her eyes to slowly creep over to peek beyond the bed. She knew what she would find, but for some reason, she held out a hope, a ridiculous hope, she knew, that she would be greeted with a typical teenager's room: dirty laundry strewn over the floor, overlaid by some magazines, posters of Karen Kain and her other favourite ballerinas posted on the wall, alongside all of her medals she'd taken home in various dance competitions. She took a deep breath in and clenched her teeth. Maybe if she clenched hard enough it wouldn't hurt as much when she saw...there it was. The same as it had been ever since she'd been discharged from the hospital. Her wheelchair. Her cage. Its silver wheels glistened coldly, the soft dark seat like a black hole that she would never be able to draw herself out of. It sat there, empty, motionless, mocking. Daring her to defy it, to leap, pirouette, or even get up and walk across the room. Knowing in the end it would be the victor, keeping her in its grasp for as long as she continued to breathe. It was the keeper of her imprisoned body and soul, which longed to once again soar together as they once had, but were instead chained to the ground, held fast by the black chair, growing more twisted and deformed with each passing day. Karen's eyes and nose burned from tears that cried to be let loose. She screwed her eyes shut and willed herself to fall back into the blissful oblivion of sleep, her one remaining refuge where she was still free to fly above all the pain and turmoil that awaited her upon awakening.

"Karen, hurry up! You know how long it takes to get ready, and we can't be late!" Karen could feel her mother peeling the blankets off of her impatiently, and her arms prickled at the cool air that swept in under the sheets. "Today is a big day for your sist-" her mother faltered for a moment, "I mean, today's recital is important for both you and your sister."

Karen cooperated half-heartedly as her mother coaxed her into a sitting position and dressed her in her favourite floral skirt. Correction: her ex-favourite floral skirt. It had been Karen's favourite when she could walk, and the wind had flirted gently with the billowing fabric, blowing it playfully around her legs as she walked, ran, skipped, or danced. Now the material just lay flat, lifeless on her emaciated legs.

She wheeled into the kitchen where her younger sister Tara sat perched on a stool at the counter, gulping down a glass of orange juice while flipping through the comics, barely even glancing up as Karen's chair squeakily announced her presence.

"Ready for your violin performance this afternoon?" Tara murmured from behind the newspaper, but Karen could tell that she wasn't really listening for an answer. She could tell that her sister was already preparing for this afternoon's performance, rehearsing in her head all the steps in the pas de deux she would perform with Ryan. The pas de deux in which Karen herself was supposed to feature. Before this. She looked longingly at the ballet shoes carelessly hanging out of Tara's dance bag by the door. There should have been two bags this morning, two happy girls in pastel leotards and garish stage makeup, chatting nervously as they prepped for the year-end recital. There were supposed to be two invitations to the National Ballet's summer camp this year, not one. Two futures in dance. Now there was only one; the other had 
been reduced to a wistful nostalgia, a hope that was as crushed and destroyed as definitively as the vehicle that had stolen it.

"I asked you a question," Tara put down the paper and her glass of orange juice and looked at Karen pointedly. "Are you ready for this afternoon?"

"Sure," Karen mumbled. As if anyone would care, or even notice how she did; all they would see was the studio's ex-star dancer in the wheelchair, and their ears would be deaf to whatever harmonies or dissonances she produced.

\section{"Well, I sure hope so!" Tara muttered.}

"What's that supposed to mean?" Karen fired back irritably. Tara shrugged evasively. Karen wondered why her sister cared, it wasn't like she herself did. The only reason Karen had resigned to play a violin solo in the first place was to end the incessant coercion coming from all directions: her ballet teacher Miss Deana, the accompanist Miss Tammy, her dance friends, and even Tara and her own mother.

Karen knew that no one had been particularly thrilled by her selection for the recital. They'd hounded her for weeks to hurry up and pick a song, then looked at her blankly when she'd finally told them. She knew everyone had been hoping for a cheery, carefree piece, as if to reassure them that even though she would never be able to dance again, she was somehow still just fine and everything would turn out just peachy keen, à la Disney Sunday Night Movie. Instead, Karen had chosen the darkest, bleakest song she could find. When she had listened to it on her computer for the first time, she'd imagined herself on the edge of a terrifying chasm, looking into its ebony maw, leaping into it, hurling herself into oblivion. Except for the last page of the piece; it spoiled the entire mood. It seemed to Karen as if someone had decided the song was too depressing and so had tacked on a falsely cheery little postlude. Well. Unlike whoever had decided the music needed lightening up, Karen had taste. She had played through it only once before crossing it out in disgust. She certainly wasn't going to ruin a perfectly good mood piece like this one. And she knew exactly where to stop. There was a three bar rest on the secondto-last page where the music paused, the audience suspended in an endless moment of utter despair before the composer had ruined the song's ominous mood with its ridiculously triumphant finale. She felt a grim satisfaction at leaving the audience in a pit of desperation, with no happiness, no joy, not even a hope of redemption. She hoped that at least for a moment, they would know her pain and despair. That is, Karen sighed to herself, if she could ever manage to reproduce the emotions portrayed in the recording. She doubted it. She didn't even know why she was even trying; she still wished she hadn't agreed to the idea in the first place. Karen resented rehearsing, because it meant facing the fact that she would no longer be dancing in any recitals. Whenever she practiced, the sounds she produced were dead and mechanical. The notes were correct and dynamics in place, but it was still lifeless. Noise instead of music. She winced when she played, for she knew what it was like to watch a dancer who possessed all the correct movements but lacked passion; no matter how technically correct they were, they could not be anything but robotic. That was how her music sounded, and she knew it. Dead, awkward, lifeless. Just like her body, and her spirit. Miss Deana had always said that dance and music revealed the artist's soul. Perhaps that was why her music was empty; for if her spirit had withered how could she expect the music to reflect anything different?

Karen paused in front of the full-length mirror on her way to the fridge. It mocked her with her own image; at first one would only notice a seated, strikingly dressed girl with tasteful makeup. But upon closer inspection, other things came into focus. The wheels attached to the black chair. The emaciated legs. The bitterness that twisted what must have once been an attractive face. The girl's hands slowly reached down to gently caress her legs in a gesture of longing before her fingers drew up to her face, tracing the sadness imprinted upon it. She stroked it tentatively, as if it were somehow foreign, that the grief and sorrow that permeated it were things that did not belong to it and whose burden she was unused to carrying.

She turned away in pain, ashamed, only to see Tara staring at her. Tara's mouth opened as if to say something, then clamped resolutely shut.

Karen's face burned in embarrassment. "Oh, just say it!" she snarled, and surprised even herself at the harshness in her voice.

"What?" Tara looked terrified. Karen took a guilty pleasure in the new power she'd held over people since the accident. It was the last vestige of life over which she felt she had any control. No one ever dared to talk back to her, for fearing one of her enraged, tearful outbursts. That, plus the fact that no one would ever want to upset "the poor little paralyzed girl," as she'd once heard someone refer to her. As if she no longer had an identity, except for that of her lack of ability to walk.

"Do you think I'm stupid?" Karen continued bitingly. "I know what you're thinking. You're dreading my bit in this recital as much as I am. Not only am I just a pathetic pity number - as if that isn't reason enough to dread watching me, thinking secretly how glad you are it isn't you sitting in this rolling prison," Karen's voice squeaked as her throat tightened, "to make it even worse, I'm going to play so horribly you won't even be able to call it 'music,' yet you'll still all clap and cheer and hurrah as if I were a virtuoso like Sarah Chang, just because you feel sorry for me."

There was an uncomfortable silence. Karen could see Tara fidget under her harsh gaze before venturing, "maybe you'll do really well?" It was a hopeful question rather than a statement.

As swiftly as it had come on, Karen's anger left, leaving her deflated. "Why does everyone have to pretend that everything will have a happy ending?" she whispered desolately, looking imploringly at Tara. "Hardly anything does. Look at all the sick kids with cancer. Or the divorce rate. Or the rainforest being chopped down. Or starving people in developing countries. Do those seem like happy endings to you?" She looked back down at her legs. What she hadn't dared say was, what about getting paralyzed when you're only 15 ? Instead, she continued softly, "what is the point of giving people hope, when there is none?" 
Another uncomfortable silence. "I...ummm...." Tara fidgeted uncomfortably. "I'll see you at recital." She grabbed her bag and fled. The gust from the slamming door ruffled Karen's skirt gently, but her legs were blind to the soft fabric that caressed them in the breeze.

"Karen! Time to go! Have you finished your breakfast?" Her mother rushed in, as usual a flurry of activity and exuding a diffuse sense of panic. Before Karen could answer, her mother continued. "I see Tara's already left with Mrs. Xiu; great. Now do you have everything with you? Violin? Music and stand? Water bottle? Coat in case you get cold? You know how chilly these theatres can get." Karen let herself be bundled out the door and lifted into the car.

Arriving at the auditorium, Karen felt a familiar shiver of nerves. But this time it was justified, she thought guiltily, thinking of her lack of practicing. But she put it out of her mind as she wheeled herself in through the stage doors. She put her head down and made a beeline for backstage, wheeling herself as fast as she could past all the dancers warming up in the halls. She could barely stand to even look at the girls and how easily they moved and stretched their supple legs, utterly oblivious to how lucky they were.

To distract herself, Karen opened a program that someone had given to her to hold for a moment - a smart move, she thought sardonically. Even if she tried to navigate the cramped backstage, whose narrow passageways were littered with dance costumes for quick changes, she certainly wasn't going anywhere in a hurry, thanks to her wheelchair.

Her eyes narrowed in disbelief as she looked at the program line-up. "What is this?" she asked incredulously to no one in particular; all the dancers were busy warming up and making last minute costume tweaks. "Karen's Song?" she asked, getting indignant, rattling the program. "Karen's Song? You guys insist I decide on a piece three months ago, "so we can put it in the program'," she imitated Miss Deana's voice. "I mean, seriously, who types up a program three frikkin' months in advance, and then can't even bother to put in what I'm actually playing? You call it Karen's Song?! Whose stupid cheeseball idea was that!" She didn't know whether to be annoyed that they hadn't even bothered to put in the correct piece, or embarrassed that they were trying to draw even more attention to her. As if featuring a paralyzed girl in a ballet recital could somehow escape notice.

"Karen, you're on!" Miss Deana rushed up to her. She knelt down so she would be at Karen's eye level and took Karen's pale clammy hands in her warm dark ones, her deep chocolate eyes piercing through Karen's distraction.

"Now, no matter what happens out there, I want you to just concentrate on the music, ok honey? Just get into your zone. It's just like dancing. Go there, and nothing can touch you." Karen nodded nervously, forgetting her fit a moment ago. She hadn't heard Miss Deana give her that pep talk in years. She'd always been so calm at recitals that no one had ever needed to remind her to get in her zone. Miss Deana must really be worried she was going to flub up big time to give her this spiel, Karen thought.
Then her throat squeezed nervously as she realized that perhaps Miss Deana hadn't been completely unjustified.

Karen tried to swallow the saliva that had thickened in her mouth, scraping her tongue across the sticky residue accumulating around her teeth. She slowly wheeled herself onto the stage towards her music, stopping halfway to wipe her slippery, sweaty hands on her skirt. She'd forgotten how hot and bright the stage lighting was, and she could feel pricks of sweat break out on her forehead and under her arms. What if she couldn't play properly? What if she froze? If people laughed? If they were all thinking what she was thinking: poor thing. How charitable to let her participate so she feels like she belongs.

The audience waited expectantly. Karen could hear a few muffled coughs and rustles. She put the violin up to her chin, and looked down at her bow quavering beneath her trembling fingers. She finally managed to nod for Miss Tammy to start. Karen tried to take a few deep calming breaths as she heard the heavy chords ring forth from the piano, trying to persuade herself that it didn't matter. She was just the freak-slash-pity show anyhow; no one actually expected anything from her. But somehow she suddenly wanted to prove herself, to prove that she was more than just a wheelchair with a body attached. She was a human being with talents and thoughts and dreams and hopes. She wanted the audience to applaud for her musicianship, not just the fact that she was a paralyzed girl playing violin.

She counted down the bars in her head until her entrance. $5 \ldots 4 \ldots 3 \ldots 2 \ldots 1 \ldots$ she started in awkwardly, wincing at her strident tone, completely out of character with the deep brooding piano chords. Her temple itched as she could feel a bead of sweat slowly wind its way down the side of her face. Get into the zone, she reminded herself. Let the audience experience what you feel. If you don't feel, neither will the audience. She could hear Miss Deana's rich, soothing voice inside her head. Dance, not movement. Music, not noise.

Karen resolutely tightened her grip on her bow. She reached down within herself and conjured up from her darkest recesses, all the pent-up anger, fear, despair, hopelessness, jealousy, bitterness, resentment. They threatened to overtake her, and she had to clench her teeth in order to stop her hands from shaking. Her entire body hummed and quivered with anguish; it took all of her willpower to keep playing. But rather than sink in and resign herself passively to her volatile emotions as she usually did, she grasped them firmly and channelled them together, focusing on how she felt, before finally letting everything explode out through her fingers. She bowed so violently she was afraid of damaging her violin, but she couldn't stop the energy pouring out through her hands. There was a sudden change to the calibre of the music; instead of strident and hesitating, it was now profound, dark, and truly foreboding. As she heard her emotions fill the auditorium, Karen's heart ached along with audience's, the sombre, dark beauty of the music making her entire being throb.

She became dimly aware of a thumping sound behind her off the stage, and felt a vibration move up from the wheelchair into the small of her back. She glanced away from her music for a moment 
nervously, in utter disbelief when her eyes confirmed what her ears had just told her. Dancers. Tara and Ryan. Doing the pas de deux. To her song. She was stunned into immobility for a moment, her concentration broken, unsure of how she felt. Angry at not being told what everyone had obviously been planning for months, instead ambushing her with it on stage? Although she knew if she'd been told, she would have refused to play. Resentful at Tara for dancing with her partner? But who was she fooling? Even before the accident, Ryan had often danced with Tara. Bitterness that she was stuck sitting in her wheelchair instead of out there dancing? Yes, Karen conceded. But she was tired of it, she realized suddenly. Tired of the anger, the resentment, the bitterness. She could not remember the last time she had actually felt happy. Or laughed. Or even smiled sincerely. She felt like she had done nothing but snap, yell, or cry since the accident. And yet, despite her hostility, people still cared enough about her to choreograph a pas de deux in her honour. Not only to the song she was playing, but for her. She suddenly realized the meaning behind her song's title printed in the program. Karen's Song.

Karen's eyes burned, announcing the imminent arrival of tears, but for the first time since she could remember, these were not tears of bitterness, but of joy. Her inclusion in the recital had not been the platitude offered out of pity she'd thought it was, but it was instead a mournful tribute to a glorious youth and a promising future cut short. A eulogy to lost innocence. To doors closed and dreams crushed. She smiled in irony as she glanced ahead to the last page of music, crossed out in angry pencil strokes. She hadn't realized the aptness of the music she'd chosen. Four pages of griefladen, dark, sorrowful melody, but followed by a transformation of that grief into hope, of darkness into light.

As she drew her bow across the strings, her fingers causing a vibrato so bittersweet that it pierced the very core of her being, she could see the pas de deux in her head. She was no longer trying to peek at Tara and Ryan through the corner of her eye. In her mind's eye she could see everything perfectly. But it was not Tara dancing, it was herself. Her partner embodied everything she had been before the accident: carefree, innocent, dream-filled. They danced a song of sorrow and deep longing. With every bar that progressed, with every step the dancers took, the sense of dread grew, the music foreshadowing what was to come; no, no, wait...I want more time...Please no, it's not fair....The dancers held each other tightly, then watched in mute horror as they saw themselves being torn apart, shredded in half through their very core. Then bleakness. Inexplicable anguish. Utter despair and loneliness.

The music stopped. The dancers paused. The silence of absolute desolation lay like a suffocating lead blanket over the theatre, slowly strangling out any memory of anything but grief and heartache. The tears that had been gathering in Karen's eyes overflowed, liquid sorrow coursing a path down her face. She hesitated for a moment, contemplating the idea of leaving the audience there, as she'd planned.

No. She could not leave anyone in such a place. No one deserved to be left there, not even herself. So she drew up her violin, and continued on to the last page of music. A faint wisp of hope quietly emerged. Small and weak at first. In her mind's eye, Karen could see herself tenuously gathering herself up, reaching out to her new partner, Hope, with tentative fingers, her hold becoming firmer as they grasped hands and started to move across the stage, slowly at first. The piano quietly joined in the lone violin, confidence growing and sound swelling with each bar. And suddenly, brilliance broke through. Blinding sunlight, streaming in from behind an impenetrable cloud. Karen's fingers moved swiftly over the strings. In her mind's eye, her partner launched her into the air into a triumphant grand jeté, then grasped her firmly around her waist and lifted her high above his head. Her body unfurled in exquisite, vulnerable beauty toward the ceiling, back arched, in perfect agony, yet in perfect hope. It lay bare and exposed, like a flower's delicate petal; so fragile, yet brimming with possibilities. Filled with hope.

Karen shut her eyes as she slowly drew the last note and let it resonate, oscillating around the room. Its sound cradled her gently. She managed a smile, her chest heaving and arms quivering from the physical effort, and from the beautiful ache born of the melding of spirit and song that she thought she'd forgotten how to feel. In the back of her mind, she heard the explosion of applause and cheers, but she kept her eyes closed. She gently caressed the smooth warm body of the violin, feeling a deep sense of peace within her, her soul's yearning finally quenched. So maybe she could no longer run or spin or leap. But she could still soar.

\section{Some people believe there's a reason for everything.}

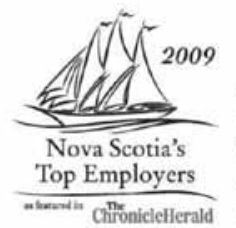

At the Colchester East Hants Health Authority we know that sometimes there are many. Certainly that's the case when it comes to explaining why we've been voted one of Nova Scotia's top employers two years in a row.

Find out more. Once you get to know us, we think you'll agree the reasons for starting your career with us are pretty clear.

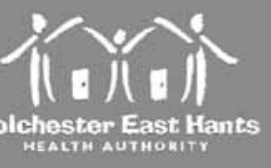

www.cehha.nshealth.ca - 902.893.5554 × 2296 - shaun.maccormick@cehha.nshealth.ca 